\title{
Characterization of plasmid pAW63, a second self-transmissible plasmid in Bacillus thuringiensis subsp. kurstaki HD73
}

\author{
Andrea Wilcks, ${ }^{1}$ Nicole Jayaswal, ${ }^{1}$ Didier Lereclus ${ }^{2}$ and Lars Andrup' \\ Author for correspondence: Andrea Wilcks. Tel: +45 39165248. Fax: +4539165201. \\ e-mail: aw@ami.dk
}

${ }^{1}$ National Institute of Occupational Health, Lersø Parkallé 105, DK-2100 Copenhagen, Denmark

2 Unité de Biochimie Microbienne, Institut Pasteur, 25 Rue du Docteur Roux, F-75724 Paris Cedex 15, France

\begin{abstract}
Bacillus thuringiensis subspecies kurstaki HD73, toxic for lepidopteran larvae, contains two large self-transmissible plasmids of approximately $75 \mathrm{~kb}, \mathrm{pHT73}$ and pAW63. The conjugative plasmid pHT73 has been studied extensively and has been shown to harbour the toxin gene cry1Ac, the transposon Tn 4430 and several insertion sequences. In this study it was demonstrated that the minor plasmid pAW63 is also self-transmissible and about 10-30 times more efficient in mobilizing plasmid pBC16. To facilitate direct selection for pAW63 transfer, the plasmid was tagged with the tetracycline resistance transposon Tn5401 and in intraspecies matings it was found that after $\mathbf{2} h$, all recipients had acquired a copy of the plasmid. Mating experiments demonstrated that pAW63 could be transferred to Bacillus thuringiensis subsp. israelensis, Bacillus cereus, Bacillus licheniformis, Bacillus subtilis and Bacillus sphaericus, and that the conjugative functions were expressed in these hosts. Hybridization studies showed that the replicons of pAW63 and pHT73 were distinct from one another. Sequences homologous to transposon Tn 4430 and several insertion sequences were, however, shown to reside on both plasmids.
\end{abstract}

Keywords: Bacillus thuringiensis, HD73, self-transmissible plasmid, conjugation, mobilization

\section{INTRODUCTION}

Bacterial conjugation is a mechanism of genetic exchange that requires cell-to-cell contact and which is not susceptible to DNase present in the mating medium. Conjugation systems are encoded by large plasmids or by conjugative transposons (Clewell, 1993; Scott, 1993), which besides being capable of transferring themselves are able to co-transfer smaller mobilizable plasmids. Conjugation is a well-known process in Gram-negative bacteria with the F plasmid from Escherichia coli being particularly well studied. The cell-to-cell contact in Gram-negative bacteria is established by the sex pilus, which retracts and brings donor and recipient cells into close physical contact (Firth et al., 1996).

In Gram-positive bacteria, DNA transfer by conjugation has been found in an increasing number of species. In these bacteria cell-to-cell contact is not mediated by pili, but other, still scarcely characterized surface structures

Abbreviations: B.t., Bacillus thuringiensis; $\mathrm{Cm}$, chloramphenicol; $\mathrm{Em}$, erythromycin; Nal, nalidixic acid; Sm, streptomycin; Tc, tetracycline. are involved. Recently, several Gram-positive systems capable of sustaining DNA transfer in liquid media have been discovered and characterized in some detail (for review, see Clewell, 1993). The best studied is the pheromone-induced conjugation system of Enterococcus faecalis (Dunny et al., 1978), which along with the conjugation systems of Lactococcus lactis (van der Lelie et al., 1991), Lactobacillus plantarum (Reniero et al., 1992) and the mosquito-toxic bacterium Bacillus thuringiensis (B.t.) subsp. israelensis (Andrup et al., 1993; Jensen et al., 1995), mediates plasmid transfer via the formation of large aggregates in liquid medium.

In 1982, González \& Carlton reported the conjugative transfer of B.t. plasmids in mixed culture which led to the discovery that the insecticidal crystal protein genes were located on large conjugative or mobilizable plasmids in several subspecies (González et al., 1982). One of the subspecies analysed was B.t. kurstaki strain HD73. B.t. kurstaki flagella serotype 3 ab comprises both strain HD1 (crystal serotype K-1) and HD73 (crystal serotype K-73) (Krywienczyk et al., 1978). Strain HD73 contains six plasmids ranging from 7.5 to $77 \mathrm{~kb}$ (González et al., 1981). The genetic basis of the insecticidal 
Table 1. Strains and plasmids

\begin{tabular}{|c|c|c|}
\hline Strain or plasmid & Relevant characteristics & Source or reference* \\
\hline \multicolumn{3}{|l|}{ B.t. kurstaki } \\
\hline $\mathrm{KT}_{\mathrm{o}}$ & & de Barjac (1981) \\
\hline HD73 & 4D4 & BGSC \\
\hline AW05 & HD73 cured of pAW63 & This study \\
\hline AW06 & HD73 cured of pHT73 & This study \\
\hline $\mathrm{AW} 16$ & $\mathrm{AW05}, \mathrm{Sm}^{\mathrm{R}}$ & This study \\
\hline AW17 & $\mathrm{AW} 06, \mathrm{Sm}^{\mathrm{R}}$ & This study \\
\hline AW21 & HD73 cured of both pAW63 and pHT73, $\mathrm{Sm}^{\mathrm{R}}$ & This study \\
\hline AW43 & HD73 cured of both pAW63 and pHT73, Nal ${ }^{\mathrm{R}}$ & This study \\
\hline AW46 & AW06 electroporated with pEG922, $\mathrm{Cm}^{\mathrm{R}}, \mathrm{Tc}^{\mathrm{R}}$ & This study \\
\hline AW48 & AW43 mated with AW46, pAW63:: Tn5401, Nal ${ }^{\mathrm{R}}, \mathrm{Tc}^{\mathrm{R}}$ & This study \\
\hline \multicolumn{3}{|c|}{ (e } \\
\hline GBJ001 & Plasmid-cured derivative, $\mathrm{Sm}^{\mathrm{R}}$ & Jensen et al. (1995) \\
\hline GBJ002 & Plasmid-cured derivative, $\mathrm{Nal}^{\mathrm{R}}$ & Jensen et al. (1996) \\
\hline AND940 & GBJ002 containing $\mathrm{pXO} 16, \mathrm{Nal}^{\mathrm{R}}$ & Jensen et al. (1996) \\
\hline \multicolumn{3}{|c|}{ Other Bacillus species } \\
\hline B. cereus & AH183 & A. B. Kolstø \\
\hline B. licheniformis & $5 \mathrm{~A} 2$ & BGSC \\
\hline B. subtilis & SB202 & L. Boe \\
\hline B. sphaericus & $13 \mathrm{~A} 5$ & BGSC \\
\hline \multicolumn{3}{|l|}{ Plasmids } \\
\hline pBC16 & Natural $B$. cereus plasmid, $\mathrm{Tc}^{\mathrm{R}}$ & Bernhard et al. (1978) \\
\hline $\mathrm{pBC} 16 \Delta \mathrm{NdeI}$ & pBC16 with a 498 bp NdeI deletion in the $m o b$ gene & Andrup et al. (1996) \\
\hline pEG588-8 & Vector containing ori-44 from B.t. HD263 & Baum et al. (1990) \\
\hline pEG922 & Tn5401 delivery vector & Baum (1994) \\
\hline pHT232 & Containing IS232A, corresponds to pHTZ232 & Menou et al. (1990) \\
\hline pHT44 & Vector containing Tn4430 & Lereclus et al. (1986) \\
\hline pHTA2 & Vector containing IS231C and $c r y 1 A b$ & Sanchis et al. (1988) \\
\hline
\end{tabular}

* The Bacillus Genetic Stock Center, Columbus, OH, USA; A. B. Kolstø, University of Oslo, Norway; L. Boe, Technical University of Denmark.

toxin has been located to a $77 \mathrm{~kb}$ plasmid in strain HD73 and it was suggested that there may be a second plasmid of similar size (González et al., 1981; Kronstad \& Whiteley, 1984). Another B.t. kurstaki strain, $\mathrm{KT}_{0}$, originating from Centre OILB (Institut Pasteur), has been shown to have a plasmid profile very similar to strain HD73 and the crystal toxin gene has been located to a $83 \mathrm{~kb}$ plasmid (Lereclus et al., 1985). We suggest that the two toxin-encoding plasmids are identical and should be named pHT73 (G. T. Vilas Boas, unpublished). It has been assumed that strain $\mathrm{KT}_{0}$ was identical to HD73 (Lereclus et al., 1985). However, as presented here, a plasmid analysis shows that strain $\mathrm{KT}_{0}$ only contains one large plasmid, the crystal toxin plasmid pHT73, whereas strain HD73 harbours a second plasmid, pAW63, somewhat smaller than pHT73. Plasmid pHT73 has been shown to contain a transposon, $\operatorname{Tn} 4430$ (Lereclus et al., 1986), and several insertion sequences (Menou et al., 1990; Mahillon et al., 1994) in addition to the toxin gene.

The objective of our study was to identify and analyse the conjugational activity of B.t. kurstaki strain HD73.
Evidence is presented that each of the two large plasmids of about $77 \mathrm{~kb}$ found in this strain, pHT73 and pAW63, is capable of bringing about its own transfer as well as that of mobilizable plasmids. Transconjugants of B.t. israelensis, Bacillus cereus, Bacillus licheniformis, $\mathrm{Ba}$ cillus subtilis and Bacillus sphaericus that inherited plasmid pAW63 were, in turn, effective donors. It appears that plasmid pAW63, under the circumstances used here, was the more efficient of the two plasmids, both with regard to conjugative transfer and as a mobilizing agent.

\section{METHODS}

Strains, plasmids and media. Bacterial strains and plasmids used in this study are listed in Table 1. Plasmids pEG922 and pEG588-8 were kindly provided by James A. Baum, Ecogen Inc., PA, USA. All cultures were grown in LB medium (Sambrook et al., 1989) containing antibiotics (Sigma), when appropriate, at the following concentrations $\left(\mu \mathrm{g} \mathrm{ml}^{-1}\right)$ : streptomycin $(\mathrm{Sm}), 100$; nalidixic acid $(\mathrm{Nal}), 15$; tetracycline $(\mathrm{Tc})$, 4; chloramphenicol $(\mathrm{Cm}), 6$. Restriction enzymes were used as recommended by the supplier (Gibco-BRL). 
Plasmid transfer. Broth mating was conducted as described by Andrup et al. (1996). Equal amounts of exponentially growing cells $\left(250 \mu\right.$ l per $\mathrm{OD}_{600}$ unit) were combined in $7 \mathrm{ml}$ prewarmed $\mathrm{LB}$ medium and incubated at $30^{\circ} \mathrm{C}$ with moderate shaking (180 r.p.m.). After $3 \mathrm{~h}$ or as indicated, appropriate dilutions were plated on selective media and controls of donors and recipients, grown separately, were tested in parallel.

To exclude plasmid transfer by transformation, $50 \mu \mathrm{g}$ DNaseI $\mathrm{ml}^{-1}$ was added to mating mixtures. As donors B.t. kurstaki strains AW05 and AW06 containing pBC16 were used and matings to strain AW43 were performed. Transduction was excluded by adding supernatant from the donor cells filtered through a $0.2 \mu \mathrm{m}$ filter to a potential recipient.

DNA isolation. Extraction of large plasmids from B.t. was conducted by the method of Jensen et al. (1995). Smaller plasmids were extracted by a modification of the alkaline-lysis method described by Andrup et al. (1993). DNA was analysed by horizontal gel electrophoresis $\left(6-10 \mathrm{~V} \mathrm{~cm}^{-1}\right)$ in 0.5 or $0.8 \%$ agarose (SeaKem GTG) with $1 \times$ TBE buffer (Sambrook t al., 1989) for 2-3 h. After electrophoresis, the gel was stained in $1 \mu \mathrm{g}$ ethidium bromide $\mathrm{ml}^{-1}$ for 5-10 min and destained in water. DNA fragments in agarose gels were purified using the QIAquick Gel Extraction Kit Protocol (Qiagen).

Electroporation. Electroporation was performed essentially as described by Bone \& Ellar (1989). Exponentially growing culture $\left(400 \mathrm{ml} ; \mathrm{OD}_{600} \approx 0.2\right)$ was chilled on ice and harvested in a precooled centrifuge. The cells were washed three times with cold water and resuspended in $500 \mu \mathrm{l}$ cold $10 \%(\mathrm{v} / \mathrm{v})$ glycerol. The resuspended cells were mixed with $1 \mu \mathrm{g}$ plasmid DNA and electroporated with a single pulse $(1200 \mathrm{~V}, 100 \Omega$, $21 \mu \mathrm{F}$ ) using GeneZapper (International Biotechnologies). The cells were resuspended in $1 \mathrm{ml}$ prewarmed LB medium and incubated at $30^{\circ} \mathrm{C}$ with moderate shaking for $3-16 \mathrm{~h}$ before plating on selective medium.

Transposon insertion in pAW63. Transposon insertion was performed as described by Jensen et al. (1996). Strain AW06 containing plasmid pAW63 was electroporated with pEG922 isolated from a B.t. israelensis strain (Jensen et al., 1996). Electrotransformants were selected on LB plates containing $\mathrm{Cm}$ and Tc. An exponentially growing culture of one of the electrotransformants, AW46, was diluted $(1: 100)$ into LB broth containing $\mathrm{Tc}$ at $42^{\circ} \mathrm{C}$ and incubated overnight at $42^{\circ} \mathrm{C}$. A mating was conducted (at $30^{\circ} \mathrm{C}$ ) with this culture as donor and a plasmid-cured, $\mathrm{Nal}^{\mathrm{R}}$ strain (AW43) as recipient. $\mathrm{Cm}^{\mathrm{s}}, \mathrm{Tc}^{\mathrm{R}}$ and $\mathrm{Nal}^{\mathrm{R}}$ transconjugants were isolated and their ability to transfer the $T c^{R}$ phenotype to a plasmid-cured $S m^{R}$ derivative of B.t. israelensis (GBJ001) was assessed. One of the transconjugants containing pAW63:: Tn5401 was designated AW48 and subsequently used in matings to determine the transfer frequency of pAW63.

Southern blotting and hybridization. DNA was transferred from the agarose gel to Hybond-N $+(0.45 \mu \mathrm{m}$, Amersham) according to the method of Southern (1975). Plasmid DNA was labelled with $50 \mu \mathrm{Ci}(1.85 \mathrm{MBq})\left[\alpha^{-{ }^{32}} \mathrm{P}\right.$ ]dCTP [Amersham; $\left.300 \mathrm{Ci} \mathrm{mM}^{-1}\left(11 \cdot 1 \mathrm{TBq}^{-1}\right)\right]$ by nick-translation using the Stratagene Prime-It II Random Primer Labelling Kit. Hybridization with the labelled probe was carried out in Quickhyb solution (Hybaid) at $65^{\circ} \mathrm{C}$ overnight. After hybridization, filters were washed twice under each of the following conditions : $2 \times$ SSPE (Sambrook et al., 1989) for $15 \mathrm{~min}$ and $0 \cdot 1 \times$ SSPE for $15 \mathrm{~min}$ at room temperature.

\section{RESULTS}

\section{Characterization of the large plasmids in strain HD73}

We isolated plasmid-cured derivatives of strain HD73 to determine the conjugative ability of each the two large plasmids pHT73 and pAW63. Strain HD73 was cured of pAW63 (resulting in strain AW05, containing only pHT73) and pHT73 (resulting in strain AW06, containing only pAW63) by growth at $42^{\circ} \mathrm{C}$ (Fig. 1, Table 1). To determine whether the two plasmids originated from a similar replicon, they were probed using the replication region ori-44 cloned in pEG588-8 (Baum et al., 1990). The ori-44 replicon is identical to that of pHT73 except for one nucleotide base change $\left(T^{301} \rightarrow\right.$ C) (Baum \& Gilbert, 1991; Gamel \& Piot, 1992). Hybridization with plasmid pEG588-8, containing ori44 , gave a signal only with AW05 containing pHT73 and no hybridization to AW06 was observed (Fig. 1). This indicates that the two plasmids are basically different with regard to their replication functions. In Fig. 1 the plasmid profiles (large plasmids) of the donor strains containing the mobilizable plasmid $\mathrm{pBC} 16$ are also shown.

\section{DNA homology between pHT73 and pAW63}

As mentioned above there was no hybridization of the replicon of pHT73 to pAW63. To test whether pHT73 and pAW63 have sequences in common, hybridization with the crystal gene $c r y 1 A b$ from B.t. aizawai 7.29 cloned into plasmid pHTA2 (Sanchis et al., 1988) was performed. cry $1 A b$ shares $86 \%$ identity to the crystal gene from pHT73, cry1Ac (Höfte \& Whiteley, 1989). As

(a)

(b)

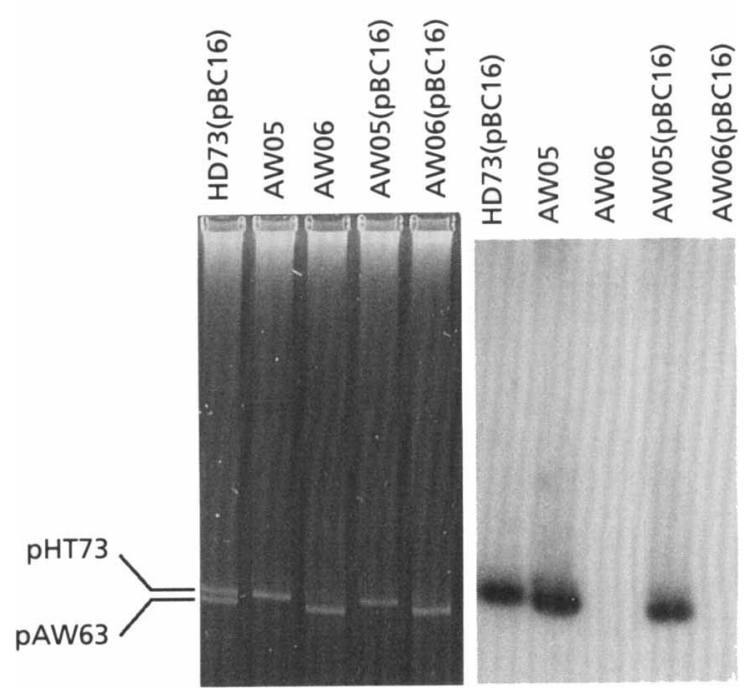

Fig. 1. (a) Agarose gel of the large plasmids from B.t. kurstaki strains (indicated above each lane) and (b) autoradiograph of Southern blot using ${ }^{32}$ P-labelled pEG588-8 containing ori-44 as probe. 
probe we used a $1 \mathrm{~kb}$ internal HindIII fragment of $c r y 1 A b$. It was found that the $c r y 1 A b$ probe only hybridized to fragments from pHT73 (Fig. 2b), so pAW63 contains no sequences with homology to the crystal gene. As seen in Fig. 2(b) the hybridization pattern of strains AW05, $\mathrm{KT}_{\mathrm{o}}$ and $\mathrm{HD} 73$ were identical, verifying that the largest plasmid, pHT73, is present in these strains. To determine whether pAW63 harboured structures similar to transposon Tn4430 found on pHT73, a $4.2 \mathrm{~kb} \mathrm{KpnI} \mathrm{fragment} \mathrm{from} \mathrm{plasmid} \mathrm{pHT44}$ (Lereclus et al., 1986), which carries a copy of Tn4430, was used as probe (Fig. 2c). It was found that $\operatorname{Tn} 4430$ hybridized to fragments of both pHT73 and pAW63. Some of the fragments were shared by both plasmids but hybridization to additional bands on pHT73 revealed that the transposon structure is not identical on these plasmids. The restriction patterns of AW05, AW06 and $\mathrm{KT}_{\mathrm{o}}$ in Fig. 2(a) showed that $\mathrm{KT}_{\mathrm{o}}$ harbours plasmid pHT73, but no bands arising from plasmid pAW63 could be detected.

A plasmid preparation from strain AW06 was digested with HindIII and used as probe in hybridization studies with the following plasmids: pHT232 (containing an internal part of IS232A as a $1.7 \mathrm{~kb}$ Clal fragment) restricted with ClaI; pHT44 (containing Tn4430 as a $4.2 \mathrm{~kb} \mathrm{KpnI} \mathrm{fragment)} \mathrm{restricted} \mathrm{with} \mathrm{KpnI;} \mathrm{pHTA2}$ (containing $c r y 1 \mathrm{Ab}$ and a part of IS231C as a $0.5 \mathrm{~kb}$ $K p n \mathrm{I} /$ PstI fragment) restricted with $K p n \mathrm{I}+P s t \mathrm{I}$ (Fig. 3). It was found that the plasmid preparation from AW06 hybridized to fragments containing Tn4430 and the insertion sequences IS232A and IS231C, while there was no hybridization to any fragment corresponding to $c r y 1 A b$. Hybridization to fragments of pHT73 (HindIII digest, Fig. 3) confirmed the partial homology between the two plasmids.

\section{Kinetics of transfer of plasmid pAW63}

By tagging pAW63 with the tetracycline resistance transposon Tn5401, resulting in the donor strain AW48 (see Methods), it was possible to follow the kinetics of transfer of pAW63:: Tn5401. Broth matings to an HD73 strain resistant to streptomycin and cured of both large plasmids (strain AW21) were conducted. During mating appropriate dilutions of the mating mixture were plated on LB without antibiotics and after growth overnight, 100 colonies were picked on to selective media for the estimation of the number of donors, recipients and transconjugants. The results of such a mating experiment are shown in Fig. 4. It was found that after $2 \mathrm{~h}$, practically all recipients had acquired a copy of plasmid pAW63:: Tn5401 and were resistant to tetracycline. That the mechanism of transfer was by the process of conjugation, rather than by transformation, was demonstrated by performing matings in the presence of DNase. DNase had no significant effect on the frequency of transfer of pBC16. To exclude phagemediated plasmid transfer, supernatant from a donor strain was added to a potential recipient strain. No transfer of $\mathrm{pBC} 16$ was detected.

\section{Mobilization of pBC16 by $\mathrm{pHT73}$ or pAW63}

The mobilizable plasmid $\mathrm{pBC} 16$ from $B$. cereus was introduced by electroporation into strains HD73, AW05 and AW06. Matings were conducted to the following recipients: AW16 ( $\mathrm{Sm}^{\mathrm{R}}$ derivative of AW05), AW17 $\left(\mathrm{Sm}^{\mathrm{R}}\right.$ derivative of AW06) and AW43 $\left(\mathrm{Nal}^{\mathrm{R}}\right.$ and cured of both pHT73 and pAW63). Table 2 shows that both pHT73 and pAW63 were able to mobilize pBC16 to the recipients. The donor harbouring pAW63 (AW06) mobilized $\mathrm{pBC} 16$ at a frequency 10-30 times higher than the donor containing pHT73 (AW05) to recipients cured of pAW63 (AW16 and AW43). In contrast to this the two donors AW05 and AW06 mobilized pBC16 to the recipient harbouring pAW63 (AW17) with similar frequency. It was found that the frequency of mobilization drastically decreased when both donor and recipient harboured pAW63, indicating entry-exclusion. The HD73 donor, which contains both pAW63 and pHT73, had a reduced frequency of transfer to the three recipients compared to mobilization from strain AW06 alone.

Both strains AW05 and AW06 were able to mobilize $\mathrm{pBC} 16$ to strains of B.t. israelensis (Table 2) and there were no significant differences in the mobilization capacity of pHT73 and pAW63. Neither did the presence of the aggregation-encoding plasmid pXO16 (Jensen et al., 1995) in the recipient strain influence the frequency of transfer of $\mathrm{pBC} 16$. Analysis of the plasmid content of the transconjugants showed that besides $\mathrm{pBC} 16$ only transfer of pAW63 was detected. None of 28 B.t. israelensis transconjugants examined received $\mathrm{pHT} 73$, while about $50 \%$ of the transconjugants from a mating with strain AW06 acquired plasmid pAW63. Subsequently, the B.t. israelensis transconjugants harbouring pAW63 and pBC16 were able to mobilize pBC16 to B.t. israelensis recipients (data not shown).

Recently Andrup et al. (1996) found that the aggregation-mediated conjugation system of B.t. israelensis encoded by pXO16 is able to mobilize pBC16 deleted for the mobilization gene, $m o b$, and for the origin of transfer oriT. To test whether a functional mob gene is necessary for mobilization by pHT73 and pAW63, the pBC16 derivative $\mathrm{pBC} 16 \Delta \mathrm{Ndel}$, which contains a deletion spanning the first half of the coding region of the $m o b$ gene, was introduced into strains AW05 and AW06. Using these strains as donors, no transfer of pBC16$\Delta N d e$ I to the recipient strain AW21 (HD73 cured of both large plasmids) was found.

\section{Transfer of pAW63 to other species and subspecies}

To investigate the host range of conjugative plasmid pAW63, matings to various Bacillus strains were conducted. Strain AW48 was used as donor of pAW63 after $3 \mathrm{~h}$ broth-mating transfer of pAW63:: Tn5401 to $\mathrm{Sm}^{\mathrm{R}}$ recipient strains of B.t. israelensis, B. cereus, B. licheniformis, $B$. subtilis and B. sphaericus was demonstrated (data not shown). Transconjugants from these matings were also capable of transferring pAW63:: Tn5401 back 


$\frac{\mathrm{AW05}}{1234} \frac{\mathrm{AW06}}{12234} \frac{\mathrm{KT}}{12234} \frac{\mathrm{HD73}}{12234 \lambda}$

(a)

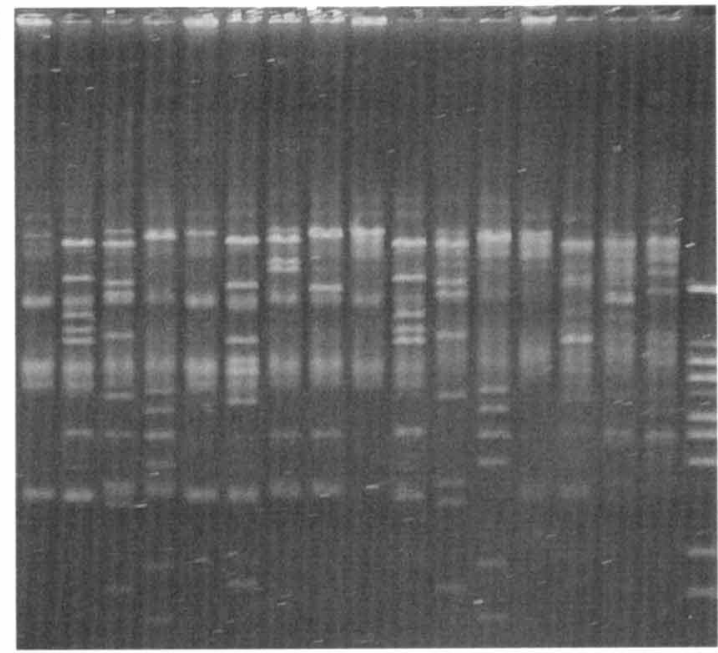

(b)

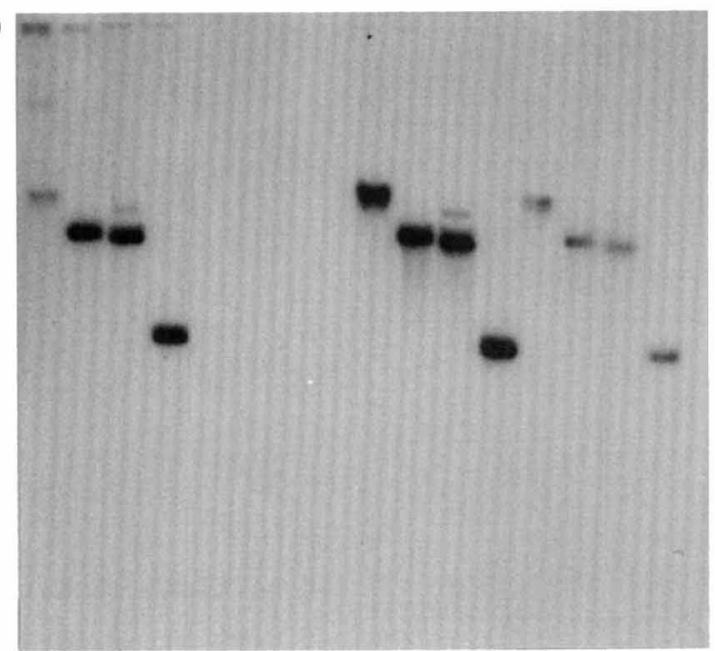

(c)

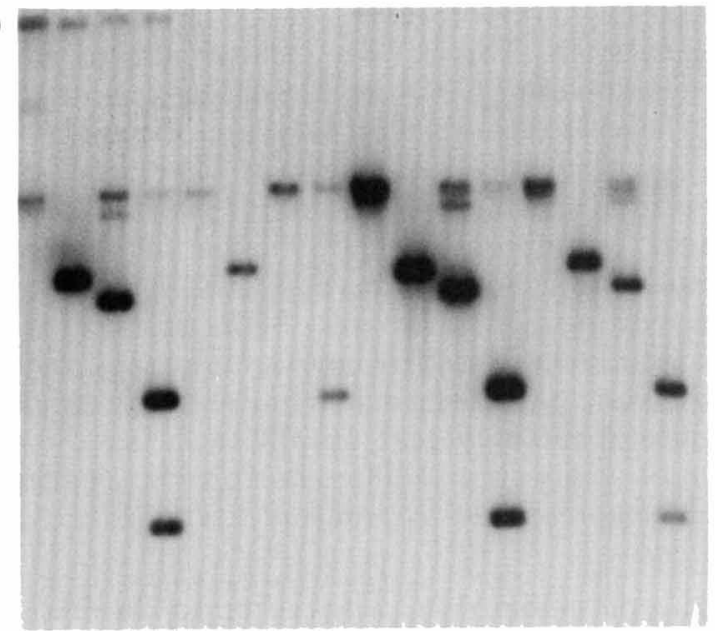

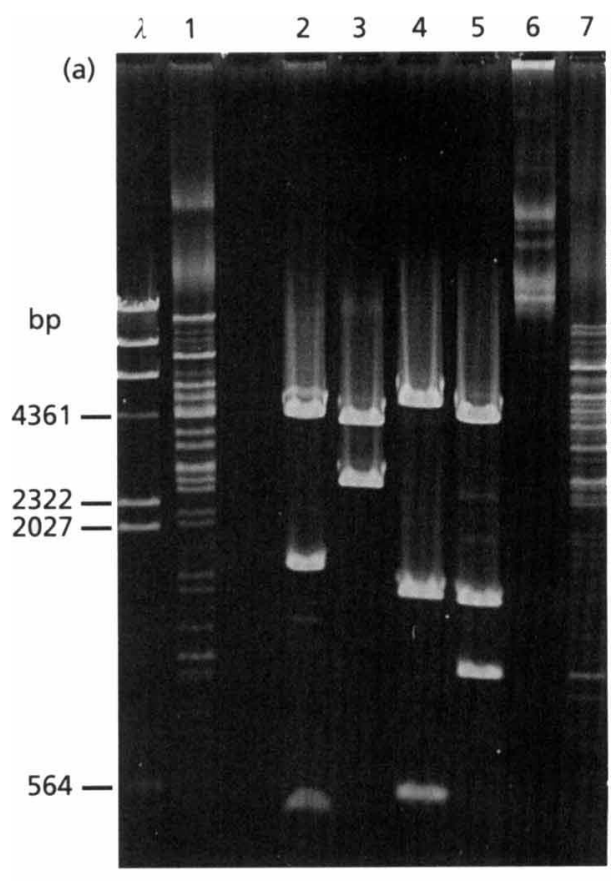

(b)

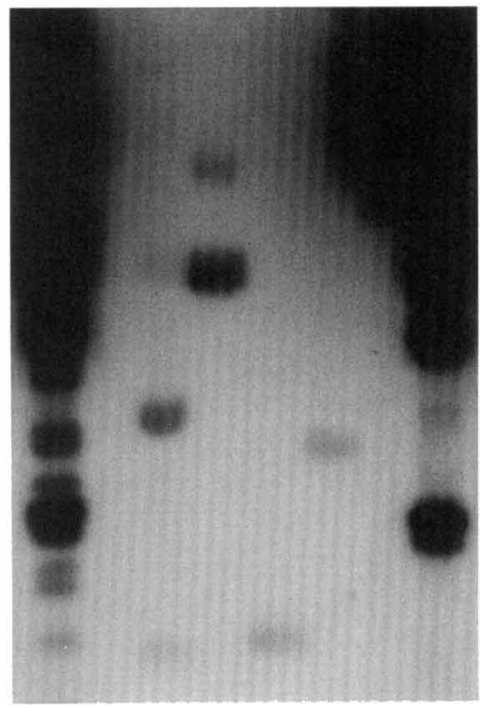

Fig. 3. (a) Agarose gel electrophoresis of: lane 1, pAW63 DNA digested with HindIII; lane 2, pHT232 digested with Clal; lane 3, pHT44 digested with Kpnl; lane 4, pHTA2 digested with Kpnl and Pstl; lane 5, pHTA2 digested with HindlII; lane 6, pHT73; lane 7, pHT73 digested with HindIII. Lane $\lambda, \lambda$ DNA digested with HindIII. (b) Autoradiograph of Southern blot using a ${ }^{32} \mathrm{p}$ labelled plasmid preparation of pAW63 digested with HindIII as probe.

to a plasmid-cured HD73 (data not shown), indicating that pAW63 is also functional in these species.

\section{DISCUSSION}

This study demonstrates that B.t. kurstaki HD73 harbours two self-transmissible plasmids, pHT73 and pAW63. González et al. (1982) reported for the first time
Fig. 2. (a) Agarose gel electrophoresis of plasmid DNA from strains AW05, AW06, KT and HD73. Lanes: 1, undigested; 2 digested with Bg/lI; 3, digested with BamHI + BstEll; 4, digested with BamHI+Pstl; $\lambda, \lambda$ DNA digested with BstEll. (b) Autoradiograph of Southern blot using ${ }^{32} \mathrm{p}$-labelled crystal toxin gene $c r y 1 A b$ as probe. (c) Autoradiograph of Southern blot using ${ }^{32}$ p-labelled transposon Tn4430 as probe. 


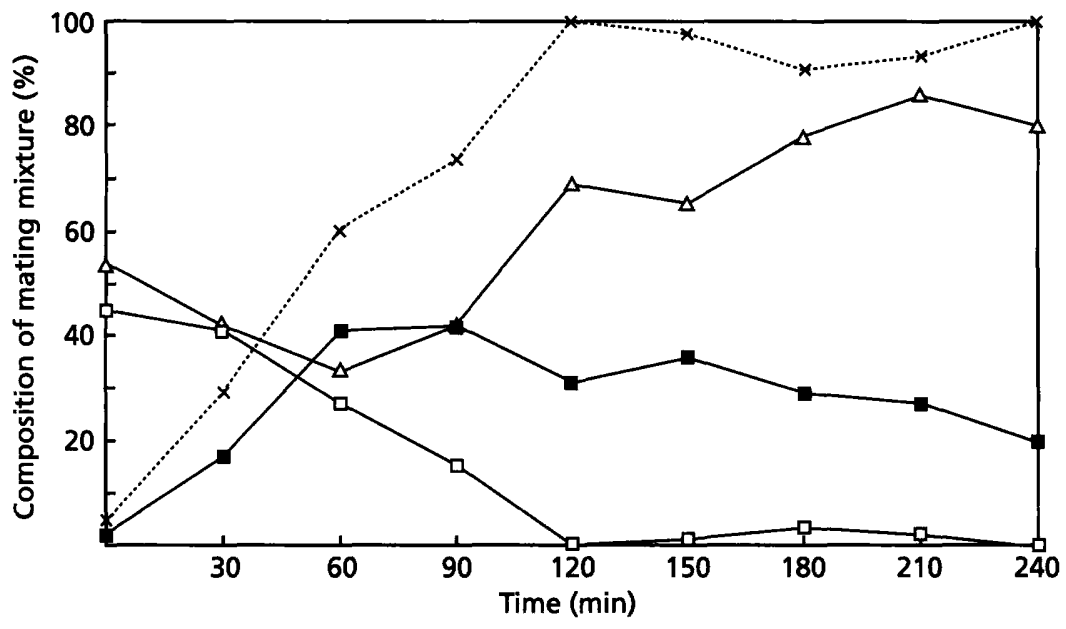

Fig. 4. Kinetics of transfer of pAW63::Tn5401 from donor strain AW48 to recipient strain AW21. Colonies (100) were picked every $30 \mathrm{~min}$ on selective agar plates for determination of the numbers of donor cells $(\triangle)$, recipient cells $(\square)$ and transconjugants ( $\square$ ). The frequency of transfer was calculated as the no. of transconjugants per recipient (dotted line).

Table 2. Mobilization of $\mathrm{pBC} 16$ by plasmids $\mathrm{pHT73}$ and pAW63

The data shown are from at least three experiments. Values shown are $\pm \mathrm{sD}$. The transfer frequency was $10^{-3}$ transconjugants per recipient. ND, Not determined.

\begin{tabular}{|lccc|}
\hline Recipients & \multicolumn{3}{c|}{ Donors } \\
\cline { 2 - 4 } & $\begin{array}{c}\text { HD73 } \\
\text { (pHT73, pAW63, pBC16) }\end{array}$ & $\begin{array}{c}\text { AW05 } \\
\text { (pHT73, pBC16) }\end{array}$ & $\begin{array}{c}\text { AW06 } \\
\text { (pAW63, pBC16) }\end{array}$ \\
\hline HD73 & & & \\
AW16(pHT73) & $0 \cdot 73 \pm 0 \cdot 07$ & $0.29 \pm 0.26$ & $3 \cdot 7 \pm 1 \cdot 0$ \\
AW17(pAW63) & $0.084 \pm 0 \cdot 017$ & $0 \cdot 20 \pm 0 \cdot 16$ & $0 \cdot 26 \pm 0.28$ \\
AW43 & $8 \cdot 7 \pm 1 \cdot 3$ & $0 \cdot 47 \pm 0.13$ & $12 \cdot 6 \pm 2 \cdot 6$ \\
B.t. israelensis & ND & $0.22 \pm 0.19$ & $1 \cdot 2 \pm 1 \cdot 1$ \\
AND940(pXO16) & ND & $0.31 \pm 0.30$ & $0.52 \pm 0.32$ \\
GBJ002 & & & \\
\hline
\end{tabular}

the transfer of pHT73 from HD73 in a conjugation-like process in broth mating. They also reported the transfer of a smaller $(66 \mathrm{~kb})$ plasmid (González \& Carlton, 1982), presumably pAW63, and they speculated whether the transfer of pHT73 was due to mobilization by the $66 \mathrm{~kb}$ plasmid. However, our work shows that both pHT73 and pAW63 are independently able to mobilize pBC16. Furthermore, pAW63 is self-transmissible to B.t. israelensis, $B$. cereus, $B$. licheniformis, $B$. subtilis and $B$. sphaericus. Under the conditions used, pAW63 was more efficient than pHT73 both regarding conjugative transfer and as a mobilizing agent. Strain $\mathrm{KT}_{0}$ has been reported to be able to mobilize smaller non-conjugative plasmids (Lereclus et al., 1985) and was formerly assumed to be identical to HD73. However, this work showed that $\mathrm{KT}_{\mathrm{o}}$ only harbours $\mathrm{pHT} 73$ and not $\mathrm{pAW} 63$, hence mobilization must be caused by pHT73.

Mobilization of non-conjugative plasmids mediated by a co-resident conjugative plasmid by the process of donation (Clark \& Warren, 1979) requires some functions on the non-conjugative plasmid: a trans-acting mob gene (encoding a mobility protein) and a cis-acting origin of transfer (oriT) (for a review, see Lanka \&
Wilkins, 1995). This has been shown also to apply to mobilization of $\mathrm{pBC} 16$, on which a mob gene and a site $\left(\mathrm{RS}_{\mathrm{A}}\right)$ suggested to function as origin of transfer (oriT) have been identified (Selinger et al., 1990), by the conjugative plasmid pLS20 in B. subtilis. However, recently Andrup et al. (1996) found that the aggregationmediated conjugation system in B.t. israelensis is capable of mobilizing derivatives of $\mathrm{pBC} 16$ deleted for both these loci. In this study, we have demonstrated that both pAW63- and pHT73-mediated mobilization require the presence of the $m o b$ gene on $\mathrm{pBC} 16$, hence the mechanism of conjugation is different from the aggregationmediated conjugation system encoded on pXO16 in B.t. israelensis.

Tagging plasmid pAW63 with the tetracycline resistance transposon Tn5401 enabled us to follow this plasmid in broth matings. We found very high transfer frequencies of pAW63 to a plasmid-cured derivative of HD73. After $2 \mathrm{~h}$ of mating more than $90 \%$ of the recipients were $\mathrm{Tc}^{\mathrm{R}}$. This is comparable with the transfer frequency found for $\mathrm{pXO16}$, the conjugative plasmid from B.t. israelensis (Jensen et al., 1996), but in contrast to this system neither $\mathrm{pHT73}$ - nor $\mathrm{pAW63-mediated} \mathrm{conjugation} \mathrm{gene-}$ 
rated visible aggregates during broth mating. By microscopic examination the mating pairs were found to comprise $2-10$ cells.

The transfer of pHT73 tagged with a gene encoding erythromycin resistance has been observed (G. T. Vilas Boas and others, unpublished). Matings were conducted both in broth culture, in soil and in infected larvae to a B.t. thuringiensis recipient. In broth mating pHT73$\mathrm{Em}^{\mathrm{R}}$ transferred at frequencies between $2.4 \times 10^{-4}$ and $1.6 \times 10^{-3}$ c.f.u. per recipient c.f.u. This is comparable to the frequency we found for pAW63:: Tn5401 transfer to recipients of B.t. israelensis.

To date, eight conjugative plasmids have been found in B.t. Two of these plasmids carry a gene for crystal production: pHT73 (from HD73 and $\mathrm{KT}_{0}$ ) and pXO12 (from thuringiensis) (Battisti et al., 1985). The other plasmids, i.e. pXO11 from B.t. thuringiensis (Battisti et al., 1985), pXO13 from B.t. morrisoni, pXO14 from B.t. toumanoffi and pXO15 from B.t. alesti (Reddy et al., 1987) have, apart from their conjugative ability, no known functions. Reddy et al. (1987) found DNA homology between pXO11, pXO12, pXO13 and pXO14 and showed that if donor and recipient contained the same conjugative plasmid, there was a reduced efficiency of pBC16 transfer, while transfer of pBC16 was enhanced if donor and recipient harboured different conjugative plasmids. Like Reddy et al. (1987) we observed entry-exclusion when both donor and recipient harboured pAW63; the transfer frequency, however, was reduced when donor and recipient each contained a different conjugative plasmid. This could indicate that pAW63 and pHT73 compete in the transfer process, perhaps by using the same system for mobilization and conjugation.

B.t. thuringiensis also harbours two conjugative plasmids: pXO12, containing the crystal toxin gene, and the cryptic plasmid pXO11 (Battisti et al., 1985). Both of these plasmids are capable of promoting the transfer of $\mathrm{pBC} 16$ to Bacillus anthracis and B. cereus, and the transconjugants harbouring either $\mathrm{pXO} 12$ or $\mathrm{pXO} 11$ are also efficient donors of $\mathrm{pBC} 16$. When B.t. thuringiensis is the donor, plasmid pXO12 is more efficient in transferring $\mathrm{pBC} 16$ than $\mathrm{pXO} 11$. This is in contrast to the situation in strain HD73 where the crystal plasmid, pHT73, is less efficient than pAW63. The benefit for a cell to have two conjugative plasmids is unknown and it would be interesting to determine whether pAW63 harbours genes, other than cry genes, but expressing adaptive functions advantageous to B.t.

Work is in progress to map pAW63 and isolate relevant genes for conjugation and replication, hopefully thereby shedding some light on the structure and properties of pAW63 and conjugation in B.t. in general.

\section{ACKNOWLEDGEMENTS}

We thank Esben Kjær Sørensen and Lasse Smidt for technical assistance and Claus A. Jarløv for his linguistic help. We are grateful to Jacques Mahillon for inspiration and encouragement and to Gert B. Jensen for critically reading the manuscript. The Danish Natural Science Research Council supported A. Wilcks and L. Andrup was supported by grants from The Carlsberg Foundation and A. N. Neergaards Fond.

\section{REFERENCES}

Andrup, L., Damgaard, J. \& Wassermann, K. (1993). Mobilization of small plasmids in Bacillus thuringiensis subsp. israelensis is accompanied by specific aggregation. J Bacteriol 175, 6530-6536.

Andrup, L., Jørgensen, O., Wilcks, A., Smidt, L. \& Jensen, G. B. (1996). Mobilization of 'non-mobilizable' plasmids by the aggregation-mediated conjugation system of Bacillus thuringiensis. Plasmid 36, 75-85.

de Barjac, H. (1981). Identification of $H$ serotypes of Bacillus thuringiensis. In Microbial Control of Pest and Plant Diseases, pp. 1970-1980. Edited by H. D. Burges. New York: Academic Press.

Battisti, L., Green, B. D. \& Thorne, C. B. (1985). Mating system for transfer of plasmids among Bacillus anthracis, Bacillus cereus, and Bacillus thuringiensis. J Bacteriol 162, 543-550.

Baum, J. A. (1994). Tn5401, a new class II transposable element from Bacillus thuringiensis. J Bacteriol 176, 2835-2845.

Baum, J. A. \& Gilbert, M. P. (1991). Characterization and comparative sequence analysis of replication origins from three large Bacillus thuringiensis plasmids. J Bacteriol 173, 5280-5289.

Baum, J. A., Coyle, D. M., Gilbert, M. P., Jany, C. S. \& GawronBurke, C. (1990). Novel cloning vectors for Bacillus thuringiensis. Appl Environ Microbiol 56, 3420-3428.

Bernhard, K., Schrempf, H. \& Goebel, W. (1978). Bacteriocin and antibiotic resistance plasmids in Bacillus cereus and Bacillus subtilis. J Bacteriol 133, 897-903.

Bone, E. J. \& Ellar, D. J. (1989). Transformation of Bacillus thuringiensis by electroporation. FEMS Microbiol Lett 58, 171-178.

Clark, A. J. \& Warren, J. (1979). Conjugal transmission of plasmids. Annu Rev Genet 13, 99-125.

Clewell, D. B. (1993). Bacterial Conjugation. New York: Plenum. Dunny, G. M., Brown, B. L. \& Clewell, D. B. (1978). Induced cell aggregation and mating in Streptococcus faecalis: evidence for a bacterial sex pheromone. Proc Natl Acad Sci USA 75, 3479-3483.

Firth, N., Ippen-Ihler, K. \& Skurray, R. A. (1996). Structure and function of the $F$ factor and mechanism of conjugation. In Escherichia coli and Salmonella, pp. 2377-2401. Edited by F. C. Neidhardt, R. Curtiss III, J. L. Ingraham, E. C. C. Lin, K. Brooks Low, B. Magasanik, W. S. Reznikoff, M. Riley, M. Schaechter \& H. E. Umbarger. Washington, DC: American Society for Microbiology.

Gamel, P. H. \& Piot, J. C. (1992). Characterization and properties of a novel plasmid vector for Bacillus thuringiensis displaying compatibility with host plasmids. Gene 120, 17-26.

González, J. M., Jr \& Carlton, B. C. (1982). Plasmid transfer in Bacillus thuringiensis. In Genetic Exchange: a Celebration and a New Generation, pp. 85-95. Edited by U. N. Streips, S. H. Goodgal, W. R. Guild \& G. A. Wilson. New York: Marcel Dekker.

González, J. M., Jr, Dulmage, H. T. \& Carlton, B. C. (1981). Correlation between specific plasmids and delta-endotoxin production in Bacillus thuringiensis. Plasmid 5, 351-365.

González, J. M., Jr, Brown, B. J. \& Carlton, B. C. (1982). Transfer of Bacillus thuringiensis plasmids coding for $\delta$-endotoxin among strains of Bacillus thuringiensis and Bacillus cereus. Proc Natl Acad Sci USA 79, 6951-6955. 
Höfte, H. \& Whiteley, H. R. (1989). Insecticidal crystal proteins of Bacillus thuringiensis. Microbiol Rev 53, 242-255.

Jensen, G. B., Wilcks, A., Petersen, S. S., Damgaard, J., Baum, J. A. \& Andrup, L. (1995). The genetic basis of the aggregation system in Bacillus thuringiensis subsp. israelensis is located on the large conjugative plasmid pXO16. J Bacteriol 177, 2914-2917.

Jensen, G. B., Andrup, L., Wilcks, A., Smidt, L. \& Poulsen, O. M. (1996). The aggregation-mediated conjugation system of Bacillus thuringiensis subsp. israelensis: host range and kinetics. Curr Microbiol 33, 228-236.

Kronstad, J. W. \& Whiteley, H. R. (1984). Inverted repeat sequences flank a Bacillus thuringiensis crystal protein gene. $J$ Bacteriol 160, 95-102.

Krywienczyk, J., Dulmage, H. T. \& Fast, P. G. (1978). Occurrence of two serologically distinct groups within Bacillus thuringiensis serotype 3ab var. kurstaki. J Invertebr Pathol 31, 372-375.

Lanka, E. \& Wilkins, B. M. (1995). DNA processing reactions in bacterial conjugation. Annu Rev Biochem 64, 141-169.

van der Lelie, D., Chavarri, F., Venema, G. \& Gasson, M. J. (1991). Identification of a new genetic determinant for cell aggregation associated with lactose plasmid transfer in Lactococcus lactis. Appl Environ Microbiol 57, 201-206.

Lereclus, D., Lecadet, M. M., Klier, A., Ribier, J., Rapoport, G. \& Dedonder, R. (1985). Recent aspects of genetic manipulation in Bacillus thuringiensis. Biochimie 67, 91-99.

Lereclus, D., Mahillon, J., Menou, G. \& Lecadet, M. M. (1986). Identification of Tn4430, a transposon of Bacillus thuringiensis functional in Escherichia coli. Mol Gen Genet 204, 52-57.

Mahillon, J., Rezsöhazy, R., Hallet, B. \& Delcour, J. (1994). IS231 and other Bacillus thuringiensis transposable elements: a review. Genetica 93, 13-26.
Menou, G., Mahillon, J., Lecadet, M. M. \& Lereclus, D. (1990). Structural and genetic organization of IS232, a new insertion sequence of Bacillus thuringiensis. J Bacteriol 172, 6689-6696.

Reddy, A., Battisti, L. \& Thorne, C. B. (1987). Identification of selftransmissible plasmids in four Bacillus thuringiensis subspecies. $J$ Bacteriol 169, 5263-5270.

Reniero, R., Cocconcelli, P., Bottazzi, V. \& Morelli, L. (1992). High frequency of conjugation in Lactobacillus mediated by an aggregation-promoting factor. J Gen Microbiol 138, 763-768.

Sambrook, J., Fritsch, E. F. \& Maniatis, T. (1989). Molecular Cloning: a Laboratory Manual, 2nd edn. Cold Spring Harbor, NY: Cold Spring Harbor Laboratory.

Sanchis, V., Lereclus, D., Menou, G., Chaufaux, J. \& Lecadet, M. M. (1988). Multiplicity of delta-endotoxin genes with different insecticidal specificities in Bacillus thuringiensis aizawai 7.29. Mol Microbiol 2, 393-404.

Scott, J. R. (1993). Conjugative transposons. In Bacillus subtilis and Other Gram-positive Bacteria: Biochemistry, Physiology, and Molecular Genetics, pp. 597-614. Edited by A. L. Sonenshein, J. A. Hoch \& R. Losick. Washington, DC: American Society for Microbiology.

Selinger, L. B., McGregor, N. F., Khachatourians, G. G. \& Hynes, M. F. (1990). Mobilization of closely related plasmids pUB110 and pBC16 by Bacillus plasmid pXO503 requires trans-acting open reading frame $\beta$. J Bacteriol 172, 3290-3297.

Southern, E. M. (1975). Detection of specific sequences among DNA fragments separated by gel electrophoresis. $J$ Mol Biol 98, 503-517.

Received 9 October 1997; revised 15 January 1998; accepted 19 January 1998. 